\title{
Direct red 83 textile dye degradation using photoperoxidation and photo-fenton: kinetic studies, toxicity and neural networks modeling
}

\author{
Nataly Daiany de Oliveira Amorim I; Graziele Elisandra do Nascimento II; \\ Lívia Vieira Carlini Charamba III; Rayany Magali da Rocha Santana IV; \\ Pollyanna Michelle da Silva v; Thiago Henrique Napoleão vi; \\ Daniella Carla Napoleão vII
}

\begin{abstract}
Textile dyes have been observed in aquatic matrices that receive effluents from different textile industries. These compounds have the peculiarity of being resistant to the physical, chemical and biological treatments commonly used in wastewater treatment plants. Thus, alternative treatments such as advanced oxidative processes (AOP) have been considered in order to promote the degradation of this type of pollutant, being the photoperoxidation and photo-Fenton processes the most used. Therefore, the present work evaluated the efficiency of these AOP in the degradation of direct red 83 dye. It was found a greater efficiency of the photoperoxidation process, especially in the degradation of functional groups observed at $289 \mathrm{~nm}$. This AOP presented a pseudo first order reaction kinetics, with rapid decay in the first minutes. The MLP (5-21-2) neural network model was able to satisfactorily predict the degradation of the dye under study. Finally, it was found that the proposed process showed no adverse effects when studying the toxicity in bacteria.
\end{abstract}

Keywords: ANN; Advanced oxidative processes; Treatment

\footnotetext{
I Universidade Federal de Pernambuco, Recife, Brazil. natalyd.amorim@gmail.com

II Universidade Federal de Pernambuco, Recife, Brazil. grazielen@yahoo.com.br

III Technische Universitat Dresden, Dresden, Germany.liviacharamba@gmail.com

IV Universidade Federal de Pernambuco, Recife, Brazil. rayanymagalirocha@gmail.com

$\checkmark$ Universidade Federal de Pernambuco, Recife, Brazil. pollyanna.michelle@gmail.com

vi Universidade Federal de Pernambuco, Recife, Brazil. thiagohn86@yahoo.com.br

vII Universidade Federal de Pernambuco, Recife, Brazil. danicarlan@gmail.com
} 


\section{INTRODUCTION}

The textile industry has been standing out in the Brazilian scenario, as it has directly participated in the growth of the country's economy. However, due to the diversity of this industry, especially in the dyeing sector, environmental problems have been observed even after the treatment of the wastewater, which is performed through conventional processes (MARTINS et al., 2011). The dyes presented in these effluents have chromophoric groups (responsible for color fixation) and aromatic groups (usually toxic) (SILVA et al., 2017).

The concern about the presence of coloring substances in the aquatic environment is related to the toxicity arising from the aromatic groups present in their molecular structures. In dyes that have one or more azo groups $(-\mathrm{N}=\mathrm{N}-)$, it is known that they can cause carcinogenic and mutagenic effects in animals, besides having allergenic effects (ZANONI; YAMANAKA, 2016; RAWAT; MISHRA; SHARMA, 2016). Additionally, the persistence of such compounds may favor the process of eutrophication in the environment and promote the reduction of solar radiation penetration, compromising the water body (SARANRAJ, 2013).

Thus, advanced oxidative processes (AOPs) have been employed as a viable alternative for the degradation of unwanted compounds as they efficiently convert recalcitrant groups into non-toxic products (ASAITHAMBI et al., 2015). The use of hydrogen peroxide as well as ultraviolet (UV) or solar radiation assist in the generation of hydroxyl radical. These, in turn, react with a vast amount of substances by removing electrons and/or hydrogen atoms from them (NAVARRO et al., 2017).

Hydroxyl radicals can react with the substances to be treated through three different mechanisms. Among these mechanisms are hydrogen abstraction reactions, which generates organic radicals (Equation 1); and union to molecular oxygen, producing peroxide radical (Equation 2). Such mechanisms give rise to chain reactions, responsible for the mineralization of the organic substrate. Thus, the result of the treatment is a clean process that should form carbon dioxide, water and inorganic salts (BRITO; SILVA, 2012).

$$
\begin{aligned}
& \mathrm{RH}+\mathrm{HO} \rightarrow \mathrm{R}^{\cdot}+\mathrm{H}_{2} \mathrm{O} \\
& \mathrm{R}+\mathrm{O}_{2} \rightarrow \mathrm{RO}_{2} .
\end{aligned}
$$


In cases where a light source is combined with hydrogen peroxide, the treatment is called photoperoxidation. However, the treatment response is often better when using the photo-Fenton process, which combines radiation, $\mathrm{H}_{2} \mathrm{O}_{2}$ and iron ions. In this process there is a photo decomposition of $\mathrm{H}_{2} \mathrm{O}_{2}$, through the regeneration of $\mathrm{Fe}^{2+}$ ions, from $\mathrm{Fe}^{3+}$ ions previously formed in the Fenton reaction (COSTA et al., 2014). Equation 3 represents the reaction of the photo-Fenton process.

$$
\mathrm{Fe}^{3+}+\mathrm{H}_{2} \mathrm{O}_{2}+h v \rightarrow \mathrm{Fe}^{2+}+\mathrm{H}^{+}+\mathrm{OH}^{-}
$$

Leite et al. (2016) state that the main indication of the efficiency of photo-Fenton dye treatment is related to the disappearance of the absorption band of the chromophoric groups. Salvador, Marcolino Júnior (2012) managed to promote the degradation of $99 \%$ of chromophoric clusters presented in QR-19 blue and reactive orange 16 dyes through this type of AOP.

However, it should be noted that regardless of the process employed, it is important to analyze the speed at which pollutant degradation reactions occur, since a very long exposure time is not feasible on an industrial scale for large effluent volumes. Another relevant factor concerns the evaluation of toxicity presented by the contaminant before and after treatment. Different species have been analyzed in order to verify the toxic potential of polluting substances, such as the bacteria. Nascimento et al. (2018) performed toxicity tests with Escherichia coli and Salmonella enteritidis strains to evaluate the behavior of reactive grey BF-2R dye before and after photo-assisted degradation. The authors found that the photo-Fenton process employing UV-C radiation did not interfere with the development of $E$. colistrains. However, this same treatment inhibited the growth of $S$. enteritidis strains, thus showing the need to perform this evaluation when working with AOP.

The present work was developed, then, with the purpose of evaluating the application of photoperoxidation and photo-Fenton $\mathrm{AOP}$ in the treatment of aqueous solution containing direct red 83 textile dye. In addition, the kinetic behavior of the treatment was evaluated and neural network modeling was used to predict process efficiency by varying different parameters.

\section{MATERIALS AND METHODS}




\subsection{Study of the degradation of aqueous solution of direct red 83 dye}

Direct red 83 azo dye (DR83) (Figure 1) has a molecular mass of $992.77 \mathrm{~g} . \mathrm{mol}^{-1}$, C.A.S 15418-16-3 and formula $\mathrm{C}_{33} \mathrm{H}_{20} \mathrm{~N}_{6} \mathrm{Na}_{4} \mathrm{O}_{17} \mathrm{~S}_{4}$. Samples of the dye solution before and after treatment were analyzed by ultraviolet-visible spectrophotometry (ThermoScientific, Genesys $10 \mathrm{~S}$ model) at 289 and $544 \mathrm{~nm}$, characteristic of the substance.

Figure 1 - Structural formula of direct red 83 dye<smiles>O=C(Nc1ccc2c(O)c(N=Nc3cc(S(=O)(=O)O)ccc3O)c(S(=O)(=O)O)cc2c1)Nc1ccc2c(S(=O)(=O)O)cc(S(=O)(=O)O)c(N=Nc3cc(S(=O)(=O)O)ccc3O)c2c1</smiles>

Source: Pellicer et al. (2018)

For the degradation tests, the advanced oxidative processes (AOPs) photo-Fenton and photoperoxidation were employed. For this, three bench reactors were used. The first with UV-C radiation (consisting of $330 \mathrm{~W}$ (Phillips) lamps, arranged in parallel), the second with UV-A radiation (containing 3 15W (Philips) lamps, arranged in parallel) and the third with artificial sunlight (using a $300 \mathrm{~W}$ power sunlight (Osram)), as shown in Figure 1.

Figure 2 - Schematic drawing of the reactors: a) UV-C, b) UV-A and c) sunlight

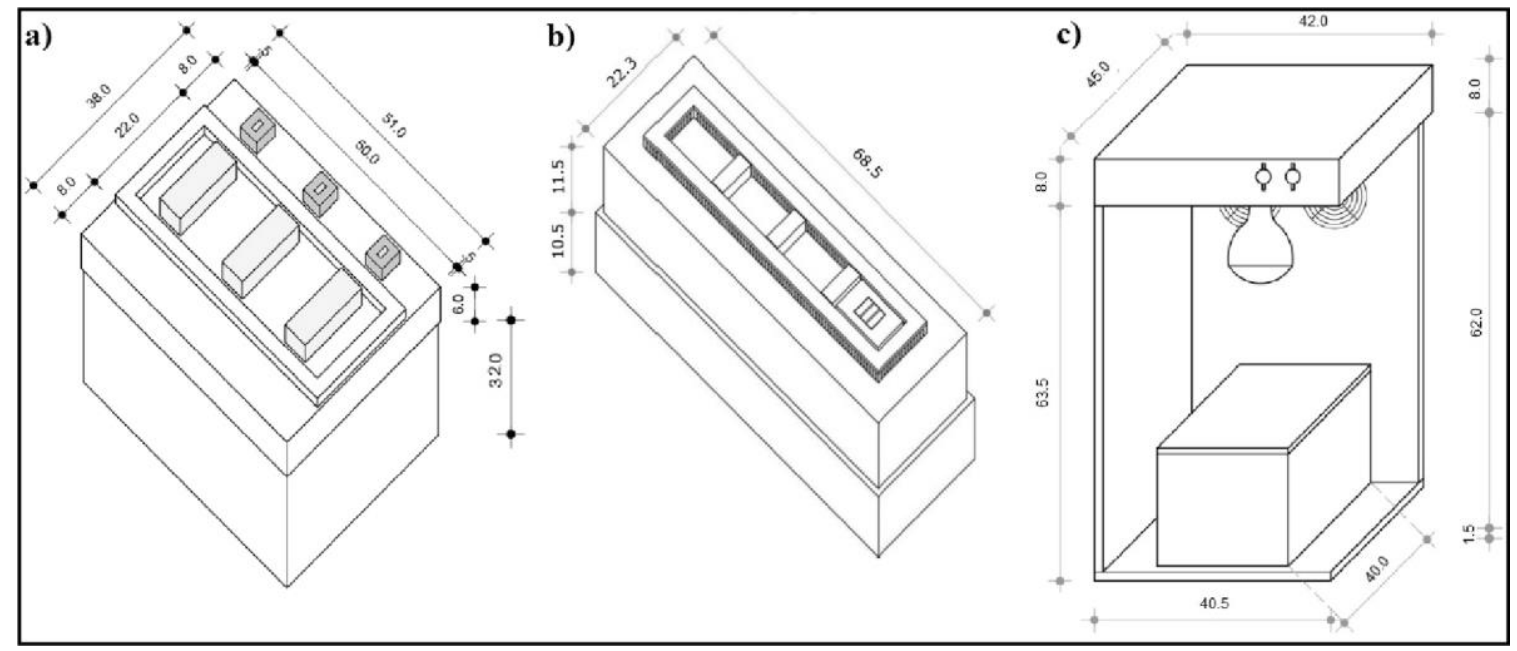

Source: Zaidan et al. (2017), Charamba et al. (2018), Santana et al. (2017) 
At first, for $60 \mathrm{~min}, 50 \mathrm{~mL}$ of dye solution with different concentrations $(5,15$ and $30 \mathrm{mg} \cdot \mathrm{L}^{-1}$ ) were submitted to both types of AOP and previously selected radiation. For the photo-Fenton process the initial $\mathrm{pH}$ was adjusted to 3 . The concentrations of iron ([Fe]) $\left(\mathrm{FeSO}{ }_{4} .7 \mathrm{H}_{2} \mathrm{O}\right.$, Vetec) and hydrogen peroxide $\left(\left[\mathrm{H}_{2} \mathrm{O}_{2}\right]\right)$ (Modern Chemistry) employed were 2.5 and $100 \mathrm{mg} \cdot \mathrm{L}^{-1}$, respectively.

Considering the AOP and the radiation that presented the highest dye degradation, the degradation conditions optimization stage was started. For this study, the $\mathrm{H}_{2} \mathrm{O}_{2}$ concentration was varied from 20, 30, 40, 50, 60, 80 to $100 \mathrm{mg}^{-\mathrm{L}^{-1}}$, while [Fe] was fixed at $2.5 \mathrm{mg} \cdot \mathrm{L}^{-1}$. The solutions were exposed to radiation for $60 \mathrm{~min}$.

\subsection{Evaluation of degradation kinetics of direct red 83 dye}

After the determination of the best AOP and the optimization of the process conditions for dye degradation, a reaction kinetic study was performed. To this end, $1 \mathrm{~L}$ of each dye solution at the three concentrations under study were subjected to radiation for $180 \mathrm{~min}$. Aliquots of $5 \mathrm{~mL}$ were taken within 10 to $180 \mathrm{~min}$. The results were submitted to adjustment to the pseudo-first order kinetic model proposed by Chan and Chu (2003) presented in Equation 4.

$$
C=C_{0} \cdot\left(1-\frac{t}{\rho+\sigma t}\right)
$$

In which, $C$ is the dye concentration ( $\mathrm{mg}^{-\mathrm{L}^{-1}}$ ) after the treatment in a reactional time $t(\mathrm{~min})$, and $C_{0}$ is the initial concentration of the dye $\left(\mathrm{mg} \cdot \mathrm{L}^{-1}\right)$. The parameters $\rho$ and $\sigma$ represent the reaction kinetics $(\mathrm{min})$ and the oxidative capacity of the system (dimensionless), respectively.

\subsection{Mathematical modeling by artificial neural networks}

Mathematical modeling of experimental data using artificial neural networks (ANN) was performed aiming at predicting the dye degradation, by considering the variables involved in the degradation process. For this purpose, Statistica software (version 10.0) was used. The neural networks employed were Multilayer Percepton (MLP) and Radial Base Function (RBF). Identity, logistic, hyperbolic, exponential, sine and hyperbolic tangential activation functions were tested. The selected inputs were: initial dye concentration ([Dye $\left.]_{0}\right)\left(\mathrm{mg} \cdot \mathrm{L}^{-1}\right)$, time $(\mathrm{min}),\left[\mathrm{H}_{2} \mathrm{O}_{2}\right]\left(\mathrm{mg} \cdot \mathrm{L}^{-1}\right),[\mathrm{Fe}]\left(\mathrm{mg} \cdot \mathrm{L}^{-1}\right)$ and $\mathrm{pH}$. Thus, an analysis of the relevance of each variable in the dye degradation percentage was 
performed. The selected output consisted of dye degradation in the $\lambda$ studied. The sampling method used was randomized with data divided into $70 \%$ for training, $15 \%$ for testing and $15 \%$ for validation. The ANNs were trained using 200 iterations and 10 repetitions, totaling 2000 iterations. The best results were based on the highest values of the linear regression coefficients $\left(R^{2}\right)$ of training, testing and validation; as well as the smallest errors obtained.

\subsection{Bacteriological toxicity assessment}

The microbiological toxicity test was performed with the dye solutions before and after treatment in sterile ultrapure water. Each sample $(450 \mu \mathrm{L})$ was incubated ( $24 \mathrm{~h}$ at 36 $\pm 1^{\circ} \mathrm{C}$ ) together with the UFPEDA 224 Escherichia coli and Salmonella enteritidis UFPEDA 414 cell suspension (50 $\mathrm{LL} ; 10^{5} \mathrm{CFU}_{\mathrm{mL}}{ }^{-1}$ in $0.15 \mathrm{M} \mathrm{NaCl}$ ) and half Mueller Hinton broth $(100 \mu \mathrm{L})$. The negative control corresponded to bacterial cells treated with sterile ultrapure water. Before and after the incubation period, the contents of each treatment were transferred to 96-well microtiter plates for reading at $600 \mathrm{~nm}$ (OD600) to determine the growth percentage. This was compared to the negative control. Additionally, aliquots of the treatments were seeded in Petri dishes containing Mueller Hinton Agar (MHA) to assess cell viability after $48 \mathrm{~h}$ incubation at $37 \pm 1^{\circ} \mathrm{C}$. Each assay was performed in triplicate and three independent experiments were performed.

\section{RESULTS AND DISCUSSION}

\subsection{Study of the degradation of aqueous solution of direct red 83}

Degradation tests were performed at the pre-determined concentrations $(5,15$ and $30 \mathrm{mg}^{\mathrm{L}-{ }^{-1}}$ ) in order to evaluate the photo-Fenton AOP and photoperoxidation, as well as the different radiation types. The results obtained regarding the degradation percentages are presented in Table 1.

Table 1 shows that photoperoxidation and photo-Fenton processes employing UV-A radiation were not efficient for the degradation of DR83 at the three concentrations evaluated. UV-C radiation, when used combined with photoperoxidation, proved to be effective with degradation greater than $79 \%$ at both wavelengths. It was also verified that the photo-Fenton process was not efficient with regard to the degradation of aromatic groups $(\lambda=289 \mathrm{~nm})$ when the initial dye concentration was $5 \mathrm{mg} \cdot \mathrm{L}^{-1}$ for all studied 
radiations. This result indicated that for dye concentrations below $5 \mathrm{mg} \cdot \mathrm{L}^{-1}$, a more detailed study of the variables involved in the process should be performed.

Table 1 - Degradation percentages obtained for the different concentrations in each studied $\lambda$

\begin{tabular}{|c|c|c|c|c|c|c|c|}
\hline \multirow{3}{*}{ AOP } & \multirow{3}{*}{ Radiation } & \multicolumn{6}{|c|}{$\%$ of degradation } \\
\hline & & \multicolumn{2}{|c|}{$5 \mathrm{mg} \cdot \mathrm{L}^{-1}$} & \multicolumn{2}{|c|}{$15 \mathrm{mg} \cdot \mathrm{L}^{-1}$} & \multicolumn{2}{|c|}{$30 \mathrm{mg} \cdot \mathrm{L}^{-1}$} \\
\hline & & $\begin{array}{l}289 \\
\mathbf{n m}\end{array}$ & 544 nm & $289 \mathrm{~nm}$ & 544 nm & $289 \mathrm{~nm}$ & $544 \mathrm{~nm}$ \\
\hline \multirow{3}{*}{ Photoperoxidation } & UV-A & NDO & NDO & 1.7 & 3.11 & NDO & 3.9 \\
\hline & UV-C & 79.5 & 99.1 & 93.9 & 97.0 & 88.1 & 94.9 \\
\hline & Sunlight & 84.4 & 91.1 & 32.9 & 58.0 & 10.6 & 26.1 \\
\hline \multirow{3}{*}{ Photo-Fenton } & UV-A & NDO & 87.5 & 59.6 & 96.1 & 79.5 & 99.6 \\
\hline & UV-C & NDO & 85.4 & 70.9 & 99.4 & 85.5 & 99.6 \\
\hline & Sunlight & 3.9 & 98.6 & 83.9 & 100.0 & 91.1 & 99.7 \\
\hline
\end{tabular}

NDO $=$ No degradation observed

Another important result was obtained by analyzing the sunlight/photoperoxidation system alone, considering the high degradation rates only for the concentration of $5 \mathrm{mg} . \mathrm{L}^{-}$ 1. The tests were repeated and the low efficiency of the system was found at concentrations equal to and/or above $15 \mathrm{mg} \cdot \mathrm{L}^{-1}$.

Table 2 - Degradation of DR83 dye employing UV-C radiation and photoperoxidation by varying $\mathrm{H}_{2} \mathrm{O}_{2}$ concentration

\begin{tabular}{|c|c|c|c|c|c|c|}
\hline \multirow{3}{*}{$\begin{array}{l}\mathrm{H}_{2} \mathrm{O}_{2} \text { concentration }\left(\mathrm{mg} . \mathrm{L}^{-}\right. \\
\left.{ }^{1}\right)\end{array}$} & \multicolumn{6}{|c|}{$\%$ of degradation } \\
\hline & \multicolumn{2}{|c|}{$5 \mathrm{mg} \cdot \mathrm{L}^{-1}$} & \multicolumn{2}{|c|}{$15 \mathrm{mg} \cdot \mathrm{L}^{-1}$} & \multicolumn{2}{|c|}{$30 \mathrm{mg} \cdot \mathrm{L}^{-1}$} \\
\hline & $289 \mathrm{~nm}$ & 544 nm & $289 \mathrm{~nm}$ & 544 nm & $289 \mathrm{~nm}$ & $544 \mathrm{~nm}$ \\
\hline 100 & 97.5 & 99.7 & 94.1 & 99.3 & 75.9 & 90.1 \\
\hline 80 & 96.7 & 99.6 & 94.2 & 99.1 & 74.9 & 91.4 \\
\hline 60 & 98.6 & 99.4 & 89.4 & 98.1 & 74.6 & 90.3 \\
\hline 50 & 97.3 & 99.6 & 93.1 & 98.6 & 67.9 & 87.6 \\
\hline 40 & 96.4 & 99.6 & 93.5 & 98.6 & 62.4 & 82.8 \\
\hline 30 & 96.9 & 98.8 & 90.4 & 98.0 & 57.9 & 78.3 \\
\hline 20 & 96.5 & 99.3 & 75.6 & 91.9 & 56.3 & 76.7 \\
\hline
\end{tabular}

Given the above, the UV-C/photoperoxidation radiation system was chosen to promote the degradation of the dye, and therefore, the influence of the process variables were evaluated. In the first phase of the optimization process, solutions containing the 
three DR83 concentrations were exposed to the selected system, employing different concentrations of $\mathrm{H}_{2} \mathrm{O}_{2}\left(20,30,40,50,60,80\right.$ and $\left.100 \mathrm{mg} . \mathrm{L}^{-1}\right)$ for $60 \mathrm{~min}$. The degradation percentages obtained are shown in Table 2.

From the data shown in Table 2, it was concluded that increasing the concentration of $\mathrm{H}_{2} \mathrm{O}_{2}$ to greater than $80 \mathrm{mg} \cdot \mathrm{L}^{-1}$ is not worthy once the degradation percentage obtained is approximately the same or even smaller compared when using $80 \mathrm{mg}^{-\mathrm{L}^{-1}}$. Thus, this value of $\mathrm{H}_{2} \mathrm{O}_{2}$ concentration was used in subsequent studies.

\subsection{Evaluation of degradation kinetics of direct red 83 dye}

The kinetic study of the photoperoxidation process was performed using $80 \mathrm{mg} \cdot \mathrm{L}^{-1}$ $\left[\mathrm{H}_{2} \mathrm{O}_{2}\right]$ and UV-C radiation. Assays were performed under atmospheric pressure and temperature of $50 \pm 1{ }^{\circ} \mathrm{C}$. For this, $1 \mathrm{~L}$ of the dye solution (in the three studied concentrations) was submitted to the treatment, being removed aliquots of $5 \mathrm{~mL}$ from it. From the results obtained, it was verified the adequacy of the data to the pseudo-first order model proposed by Chan and Chu (2003), as can be observed in Figure 3.

Figure 3. Kinetics of direct red 83 dye degradation with adjustment to the model proposed by Chan and Chu at initial concentrations of: a) $5 \mathrm{mg} \cdot \mathrm{L}^{-1}$, b) $15 \mathrm{mg} \cdot \mathrm{L}^{-1}$; c) $30 \mathrm{mg} \cdot \mathrm{L}^{-1}$

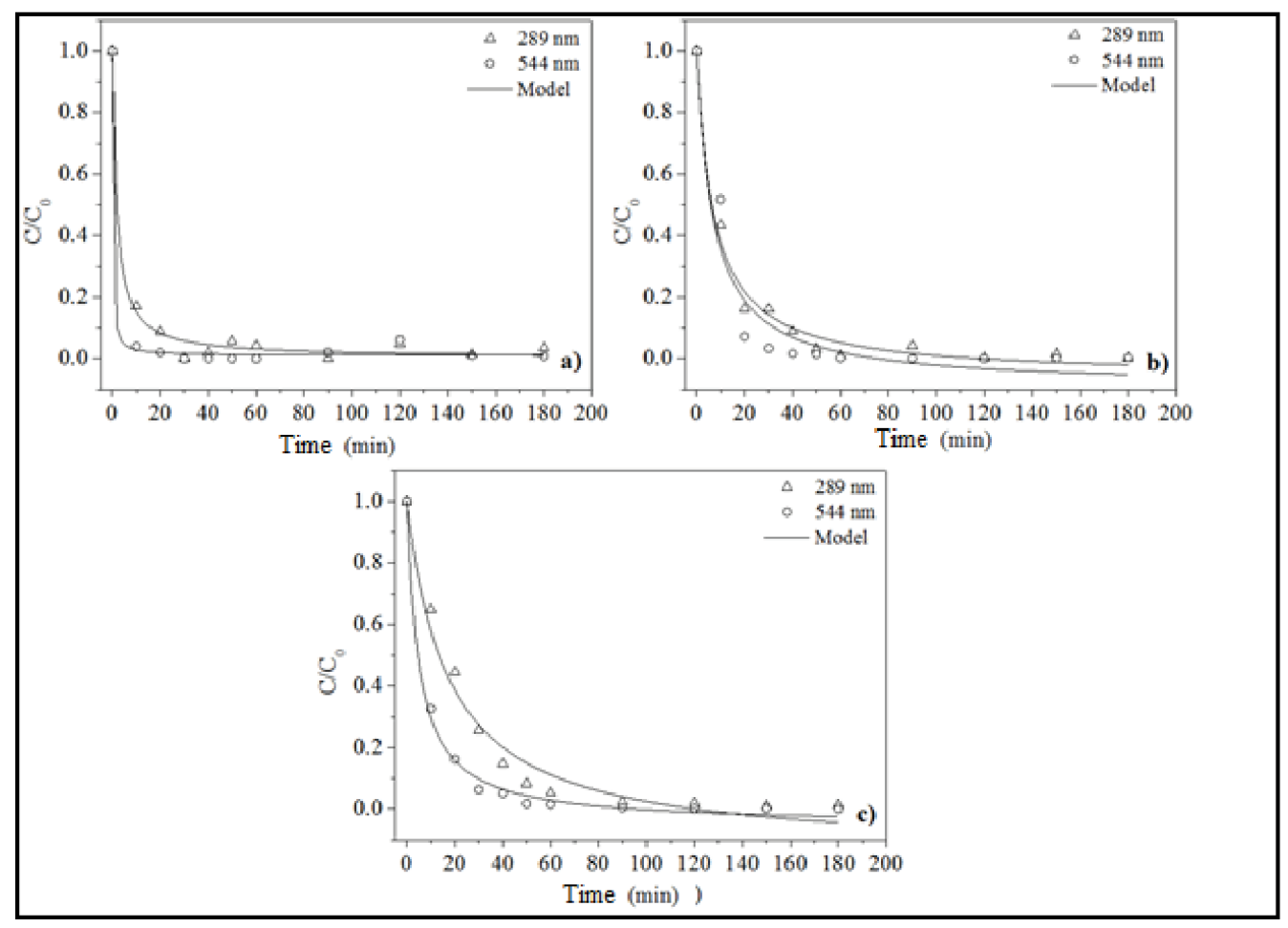

It was possible to verify, through the analysis of Figure 3, the stabilization of the system after 30, 50 and 60 min of exposure. The degradations obtained were greater than 
99, 98 and $97 \%$ for the concentrations of 5, 15 and $30 \mathrm{mg} . \mathrm{L}-1$, respectively, for both dyes. The values of the linear regression coefficients and the other kinetic parameters of the oxidation reaction can be observed in Table 3 .

Table 3 - Kinetic Parameters

\begin{tabular}{|c|c|c|c|c|c|c|}
\hline \multirow{2}{*}{ Parameters } & \multicolumn{2}{|c|}{$5 \mathrm{mg} \cdot \mathrm{L}^{-1}$} & \multicolumn{2}{|c|}{$15 \mathrm{mg} \cdot \mathrm{L}^{-1}$} & \multicolumn{2}{|c|}{$30 \mathrm{mg} \cdot \mathrm{L}^{-1}$} \\
\hline & $289 \mathrm{~nm}$ & $544 \mathrm{~nm}$ & $289 \mathrm{~nm}$ & $544 \mathrm{~nm}$ & $289 \mathrm{~nm}$ & $544 \mathrm{~nm}$ \\
\hline $1 / \rho^{\mathrm{a}}$ & 0.57 & 5.24 & 0.15 & 0.16 & 0.07 & 0.21 \\
\hline $1 / \sigma^{b}$ & 1.00 & 1.00 & 1.06 & 1.07 & 1.04 & 1.05 \\
\hline $\mathrm{R}^{2}$ & 0.99 & 0.99 & 0.98 & 0.94 & 0.97 & 0.99 \\
\hline
\end{tabular}

$1 / \rho^{\mathrm{a}}$ : initial removal rate; $1 / \mathrm{\sigma}^{\mathrm{b}}$ : maximum oxidation capacity.

The $R^{2}$ values presented in Table 3 showed a good fit of the experimental data to the Chan and Chu model. The initial removal rates (1/ $\rho)$ were higher at $544 \mathrm{~nm} \lambda$ for the three concentrations studied, obtaining faster compound reduction ratios. The maximum oxidation capacities of the system $(1 / \sigma)$ were similar for the three concentrations in both. Thus, it can be stated that the kinetic behavior of dye degradation via photo-peroxidation is similar for the studied concentrations $\left(5,15\right.$ and $\left.30 \mathrm{mg}^{-\mathrm{L}^{-1}}\right)$.

\subsection{Mathematical modeling by artificial neural networks}

The effect of the variables [Dye $]_{0}$, time, $\left[\mathrm{H}_{2} \mathrm{O}_{2}\right],[\mathrm{Fe}]$ and $\mathrm{pH}$ were evaluated in the photoperoxidation process using UV-C radiation. Experimental data obtained under different operating conditions were modeled using ANN. Among the ANNs employed, it was found that the RBF function was not as accurate to describe the data, and therefore the best result was obtained when applying the MLP network. This, in turn, resulted in 21 hidden layer neurons (5-21-2), whose architecture is shown in Figure 4. It was found that the training algorithm employed was based on the Broyden, Fletcher, Goldfarb and Shanno methods (BFGS). The activation functions of the input and output layers were Tanh and Logistic, respectively. 
Figure 4 - ANN MLP`s architecture 5-21-2

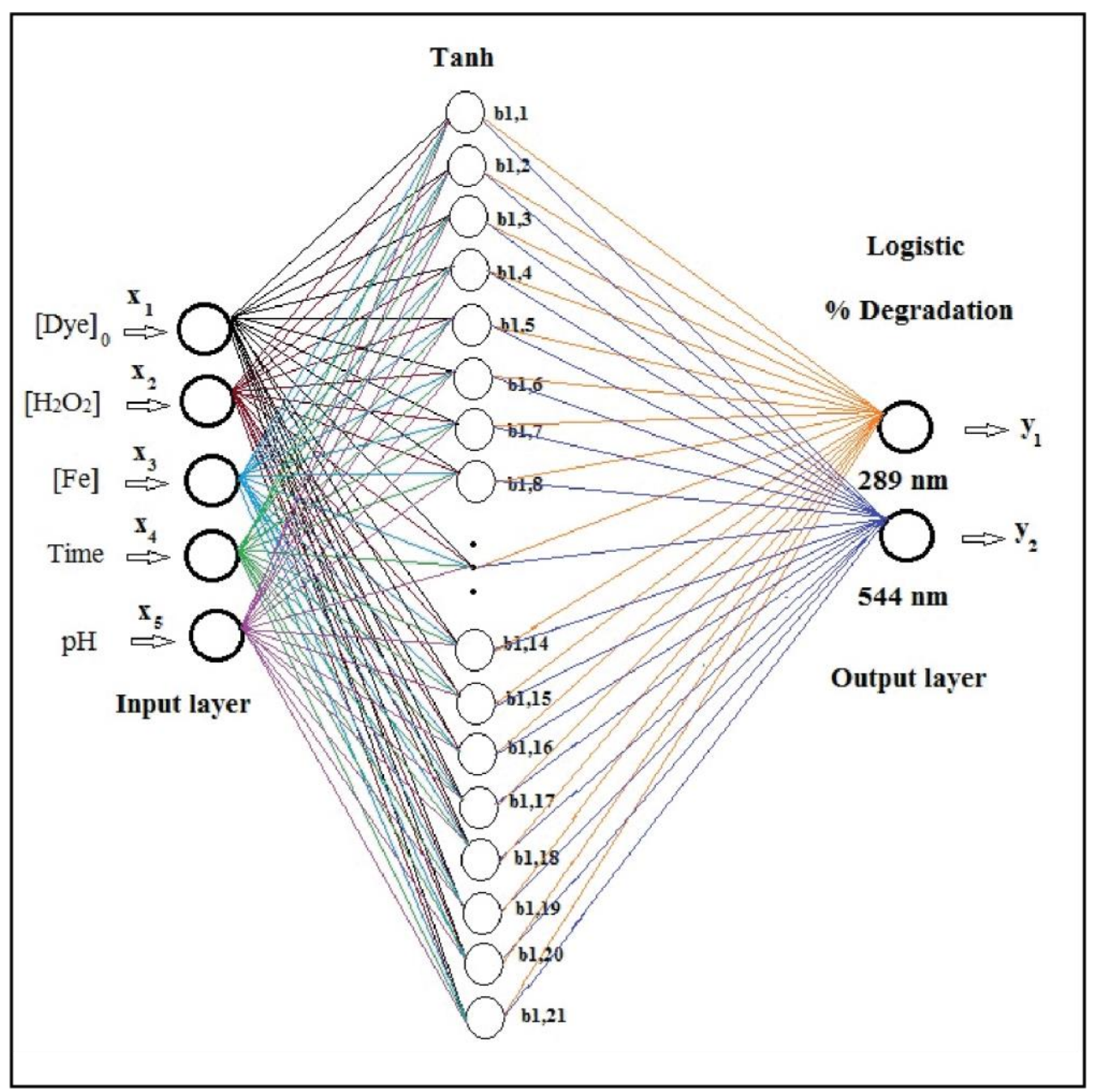

From the results obtained with ANN MLP 5-21-2 it was possible to determine the relative importance of the input variables in the dye degradation efficiency. For both $\lambda$, the variables influenced the dye degradation in a similar way, with $\mathrm{pH}$ being the most influential factor (on average 37.76\%). Then, important contributions were given by the variables $[\text { Dye }]_{0}(\approx 24.12 \%)$, Time $(\approx 19.81 \%)$ and $[\mathrm{Fe}](\approx 13.25 \%)$. The variable $\left[\mathrm{H}_{2} \mathrm{O}_{2}\right]$ presented the lowest contribution among the studied factors $(\approx 5.06 \%)$.

The ANN model developed to predict dye degradation was tested for accuracy. In this case, the values predicted by the network were compared with those obtained in the corresponding experiments, as can be observed in Figure 5. 
Figure 5 - Parity graphs of the models used in training, testing and validation for the studied $\lambda$

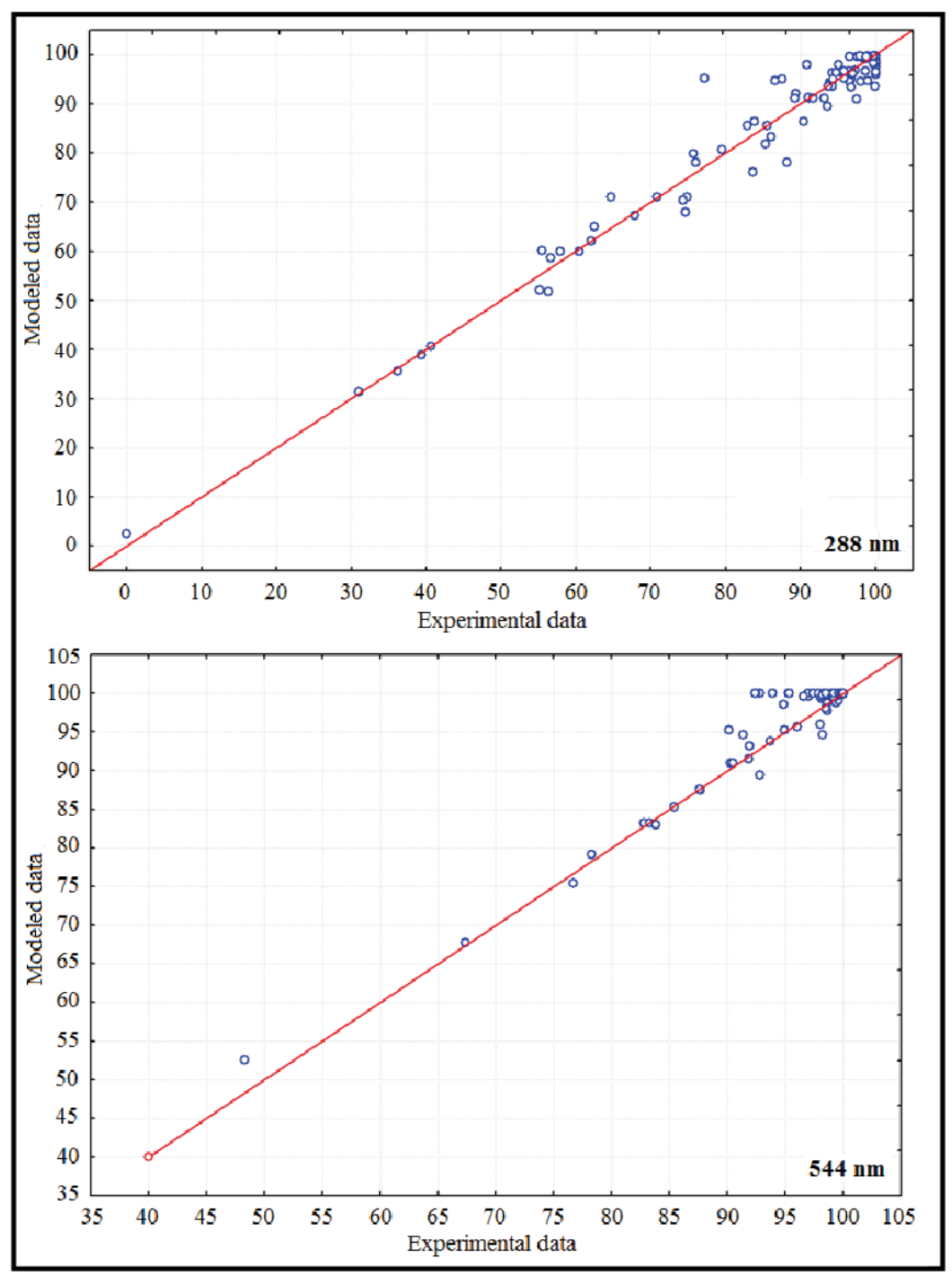

Figure 5 represents the comparative analysis between the calculated and experimental dye degradation values for the data set distributed among the training, testing and validation subgroups. From the analysis of this figure, it was found that the data showed no dispersion trends, confirming that the MLP 5-21-2 was adequate to predict the performance of the DR83 dye degradation process. In addition, the reliability of the ANN was verified from the linear regression coefficients $\left(R^{2}\right)$ obtained for the output variable, which were higher than 0.98 and 0.97 for the $\lambda$ of 289 and $544 \mathrm{~nm}$, respectively. Similar results were obtained by Nascimento et al. (2018) that by employing ANN, it was verified that MLP type with BFGS training algorithm was able to predict the degradation of reactive gray textile azo dye using AOP with UV-C radiation. 


\subsection{Bacteriological toxicity assessment}

In this study, samples of the solution containing the CR83 dye were evaluated at the three initial concentrations $\left(5,15\right.$ and $\left.30 \mathrm{mg}^{-\mathrm{L}^{-1}}\right)$ before and after treatment. The results obtained for the two bacteria studied are shown in Table 4.

Table 4 - Growth percentage and cell viability of Escherichia coli and Salmonella enteritidis bacteria

\begin{tabular}{|c|c|c|c|}
\hline \multicolumn{4}{|c|}{ Escherichia coli } \\
\hline \multirow{2}{*}{ Samples } & $t_{24 h}-t_{0 h}$ & \multirow{2}{*}{ Growth (\%) } & \multirow{2}{*}{ Viability } \\
\hline & Average $\pm \sigma\left(\mathrm{DO}_{600}\right)$ & & \\
\hline Water (control) & $0.310 \pm 0.017$ & 100.0 & +++ \\
\hline Before the treatment $\left(5 \mathrm{mg} \cdot \mathrm{L}^{-1}\right)$ & $0.248 \pm 0.019$ & 77.98 & ++ \\
\hline Before the treatment $\left(15 \mathrm{mg} \cdot \mathrm{L}^{-1}\right)$ & $0.297 \pm 0.023$ & 89.65 & ++ \\
\hline Before the treatment $\left(30 \mathrm{mg} \cdot \mathrm{L}^{-1}\right)$ & $0.279 \pm 0.018$ & 89.80 & ++ \\
\hline After the treatment $\left(5 \mathrm{mg} \cdot \mathrm{L}^{-1}\right)$ & $0.250 \pm 0.026$ & 80.63 & ++ \\
\hline After the treatment $\left(15 \mathrm{mg} \cdot \mathrm{L}^{-1}\right)$ & $0.302 \pm 0.016$ & 97.37 & +++ \\
\hline After the treatment $\left(30 \mathrm{mg} \cdot \mathrm{L}^{-1}\right)$ & $0.298 \pm 0.001$ & 95.92 & +++ \\
\hline \multicolumn{4}{|c|}{ Salmonella enteritidis } \\
\hline Water (control) & $0.256 \pm 0.022$ & 100.0 & +++ \\
\hline Before the treatment $\left(5 \mathrm{mg} \cdot \mathrm{L}^{-1}\right)$ & $0.187 \pm 0.029$ & 74.45 & ++ \\
\hline Before the treatment $\left(15 \mathrm{mg} \cdot \mathrm{L}^{-1}\right)$ & $0.241 \pm 0.027$ & 90.12 & ++ \\
\hline Before the treatment $\left(30 \mathrm{mg} \cdot \mathrm{L}^{-1}\right)$ & $0.203 \pm 0.013$ & 79.28 & ++ \\
\hline After the treatment $\left(5 \mathrm{mg} \cdot \mathrm{L}^{-1}\right)$ & $0.197 \pm 0.023$ & 76.94 & ++ \\
\hline After the treatment $\left(15 \mathrm{mg} \cdot \mathrm{L}^{-1}\right)$ & $0.253 \pm 0.028$ & 98.76 & +++ \\
\hline After the treatment $\left(30 \mathrm{mg} \cdot \mathrm{L}^{-1}\right)$ & $0.265 \pm 0.007$ & 103.44 & +++ \\
\hline
\end{tabular}

Through the analysis of Table 4 and according to the percentage of bacterial growth, it was possible to observe that the dye DR83 presented low toxicity. It was also found that AOP treatment did not give toxicological effects to the solution, which can also be observed by the increase of cell viability. By analyzing cell growth in isolation, it was found that there was no significant difference for the obtained optical density (OD) values of the samples before and after treatment, as well as in relation to the negative control. 


\section{CONCLUSION}

The use of photoperoxidation and photo-Fenton as treatments to promote the degradation of the direct red 83 dye proved to be efficient in the deterioration of the chromophore group, responsible for conferring the characteristic coloration of the studied compound. However, it was noticed that by analyzing the decrease in absorbance in the length of $289 \mathrm{~nm}$, only the photoperoxidation process was efficient for the three concentrations studied. This optimized treatment presented a nonlinear pseudo-first order kinetics, with adjustment greater than $0.94\left(R^{2}\right)$ for the two $\lambda$ and the three concentrations evaluated. It was also found that the ANN MLP model (5-21-2) can satisfactorily predict the percentage of direct red 83 dye degradation based on the input variables: [Dye $]_{0},\left[\mathrm{H}_{2} \mathrm{O}_{2}\right],[\mathrm{Fe}]$, time and $\mathrm{pH}$. Finally, it was found that the possible intermediates formed after degradation did not have toxicological effects against strains of bacteria Escherichia coli and Salmonella enteritidis, thus confirming the efficiency of the treatment with regard to the toxicity of the formed solution.

\section{ACKNOWLEDGMENTS}

The authors thank PIBIC/UFPE, FADE/UFPE and NUQAAPE/FACEPE.

\section{REFERENCES}

ASAITHAMBI, P.; SARAVANATHAMIZHAN, R.; MATHESWARAN, M. Comparison of treatment and energy efficiency of advanced oxidation processes for the distillery wastewater. Int. J. of Environ. 2015;12(7): 2213-2220.

BRITO, N. N. D.; SILVA, V. B. M. Processos oxidativos avançados e sua aplicação ambiental. Revista Eletrônica de Engenharia Civil. 2012; 1(3): 36-47.

CHAN, K. H.; CHU, W. Modeling the reaction kinetics of Fenton's process on the removal of atrazine. Chemosphere. 2003; 51(4):305-311.

CHARAMBA, L. V. C., SANTAXNA, R. M. R., NASCIMENTO, G. E., CHARAMBA, B. V. C., MOURA, M. C., COELHO, L. C. B. B., OLIVEIRA, J. G. C., DUARTE, M. M. M. B., NAPOLEÃO, D. C. Application of the advanced oxidative process on the degradation of the green leaf and purple açaí food dyes with kinetic monitoring and artificial neural network modelling. Water Sci Technol. 2018; 78:1094-1103. 
COSTA, F. M.; CAMPOS, J. C.; FONSECA, F. V.; BILA, D. M. Tratamento de lixiviados de aterros de resíduos sólidos utilizando processos Fenton e foto-Fenton Solar. Rev. Ambient. Água. 2014; 10(1):107-116.

LEITE, L. S.; MASELLI, B. S.; UMBUZEIRO, G. A.; NOGUEIRA, R. F. P. Monitoring ecotoxicity of disperse red 1 dye during photo-Fenton Degradation. Chemosphere. 2016; 158(1):511-517.

MARTINS, L. M.; SILVA, C. E.; MOITA NETO, J. M.; LIMA, A. S.; MOREIRA, R. F. P. M. Aplicação de Fenton, foto-Fenton e $\mathrm{UV} / \mathrm{H}_{2} \mathrm{O}_{2}$ no tratamento de efluente têxtil sintético contendo o corante Preto Biozol UC. Engenharia Ambiental e Sanitária. 2011; 16(3):261-270.

NASCIMENTO, G. E.; NAPOLEÃO, D. C; SILVA, P. K. A.; SANTANA, R. M. R.; BASTOS, A. M. R.; ZAIDAN, L. E. M. C.; MOURA, M. C.; COELHO, L. C. B. B.; DUARTE, M. M. M. B. Photo-Assisted Degradation, Toxicological Assessment, and Modeling Using Artificial Neural Networks of Reactive Gray BF-2R Dye, Water Air Soil Pollut. 2018; 229:379.

NAVARRO, P.; GABALDÓN, J. A.; GÓMEZ-LÓPEZ, V. M. Degradation of an azo dye by a fast and innovative pulsed light $/ \mathrm{H}_{2} \mathrm{O}_{2}$ advanced oxidation process. Dyes and Pigm. 2017; 136(1):887-892.

PELLICER, J. A., RODRÍGUEZ-LÓPEZ, M. I., FORTEA, M. I., HERNÁNDEZ, J. A. G., LUCASABELLÁN, C., MERCADER-ROS, M. T., SERRANO-MARTÍNEZ, A., NÚNEZ-DELICADO, E., COSMA, P., FINI, P., FRANCO, E., GARCÍA, R., FERRÁNDIZ, M., PÉREZ, E., Franco, E. Removing of Direct Red 83: 1 using a-and HP-a-CDs polymerized with epichlorohydrin: Kinetic and equilibrium studies. Dyes Pigm. 2018; 149:736-746.

RAWAT, D.; MISHRA, V.; SHARMA, R. S. Detoxification of azo dyes in the context of environmental processes. Chemosphere. 2016; 155:591-605.

SALVADOR, T.; MARCOLINO JÚNIOR, L. H.; PERALTA-ZAMORA. Degradação de corantes têxteis e remediação de resíduos de tingimento por processo de Fenton, foto-Fenton e eletro-Fenton. Quim. Nova. 2012; 35(5): 932-938.

SANTANA, R. M. R; CHARAMBA, L. V. C.; NASCIMENTO, G. E.; OLIVEIRA, J. G. C.; SALES, D. C. S.; DUARTE, M. M. M. B.; NAPOLEÃO, D. C. Degradation of Textile Dyes Employing Advanced Oxidative Processes: Kinetic, Equilibrium Modeling, and Toxicity Study of Seeds and Bacteria Water Air Soil Pollut. 2019; 230:136.

SARANRAJ, P. Bacterial biodegradation and decolourization of toxic textile azo dyes. Afr. J. Microbiol. Res. 2013; 7(30): 3885-3890.

SILVA, L. R. C.; SILVA, T. L.; ARAÚJO, F. P.; SILVA FILHO, E. C.; OSAJIMA. J. A. Uso de fotólise direta e $\mathrm{H}_{2} \mathrm{O}_{2} / \mathrm{UV}$ em solução aquosa contendo o corante violeta cristal. Holos Environment. 2017; 17:138-148.

ZAIDAN, L. E. M. C.; PINHEIRO, R. B.; SANTANA, R. M. R.; CHARAMBA, L. V. C.; NAPOLEÃO, D. C.; SILVA, V. L. Evaluation of efficiency of advanced oxidative process in degradation of 2-4 dichlorophenol employing UV-C radiation reactor. REGET. 2017; 21(2):147-157. 
ZANONI, M. V. B., YAMANAKA, H. (2016). Corantes: caracterização química, toxicológica, métodos de deteç̧ão e tratamento (1st ed.). São Paulo: Cultura Acadêmica. 